\title{
Energy and historic buildings: toward evidence-based policy reform
}

\author{
Erica Avrami, Jennifer L. Most, Anna Gasha and Shreya M. Ghoshal \\ Graduate School of Architecture, Planning, and Preservation, Columbia University, \\ New York, New York, USA
}

\begin{abstract}
Purpose - This research informs the intersection of climate and heritage policy development by examining the history of US energy policy as it relates to historic buildings, emerging policy tools to reduce greenhouse gas emissions, and the implications of a changing legislative landscape on historic buildings through the case of New York City.

Design/methodology/approach - This study employs a multi-method approach, including a review of US energy codes; discourse analysis of government records, energy studies, and reports related to historic buildings and energy; select research into energy-related heritage policy at the municipal level; and geospatial and statistical methods to analyze policy implications in the case study of New York City.

Findings - Historic buildings have long been afforded exemptions from energy code compliance in the US, and these waivers are widespread. Contemporary operating energy and greenhouse gas data, as well as energy justice findings about whom these waivers privilege, challenge these exemptions and signal a need for significant policy reform in light of climate change.

Originality/value - This study questions longstanding rhetoric about historic buildings being inherently green and supports the need for more evidence-based research to undergird heritage policy reform that is equitable and climate-responsive.
\end{abstract}

Keywords Climate change, Historic cities, Legal and institutional issues, Operating energy, Embodied energy, Energy regulation, Greenhouse gas emissions, Energy justice, Historic preservation, New York City

Paper type Research paper

\section{Introduction}

Model energy codes in the United States (US) provide exceptions for historic buildings, meaning they do not need to meet energy performance standards, and these exemptions are echoed in state and municipal legislation across the country. The exemptions date to the 1970s, when preservationists effectively argued that historic buildings warranted special consideration, and justified their assertions based on limited, and now outdated, research on the operating and embodied energy of old buildings. At the time, during the US oil crisis, economic rationales undergirded the energy cost-saving rhetoric and established a structural legacy of regulation that continues to allow historic preservation concerns to outweigh energy efficiency. Today, the built environment accounts for $40 \%$ of energy consumption (US EIA) and $35 \%$ of carbon dioxide $\left(\mathrm{CO}_{2}\right)$ emissions in the US (US EIA). The current climate crisis, and the knowledge it has generated, compels policy reform that holds all buildings, including historic ones, to account.

This research charts the history of US energy policy as it relates to historic buildings, explores new policy tools that are emerging in the climate era, and examines the implications of a changing legislative landscape on the preservation enterprise through the case of New York City (NYC). This case starkly illustrates the impact of the longstanding privileges afforded historic properties, where almost one-third (32\%) of the built floor area of Manhattan is energy code-exempt due to historic status. It also raises critical questions regarding the

This research was supported by the Columbia University Graduate School of Architecture, Planning, and Preservation.

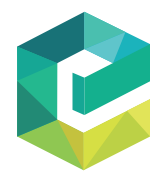

Journal of Cultural Heritage Management and Sustainable Development 2044-1266

This work is deposited under a Creative Commons Attribution Non-commercial International Licence 4.0 (CC BY-NC 4.0). For more information, see https://creativecommons.org/licenses/by-nc/4.0/.

Non-commercial reuse is allowed in accordance with the terms outlined by the licence. For

commercial reuse, contact permissions@emeraldinsight.com 
energy justice implications of these exemptions. Despite these code waivers, the recent introduction of greenhouse gas (GHG) legislation will likely incur the retrofitting of many historic NYC buildings, whether due to onsite energy generation, such as photovoltaics, or conversion to all-electric systems. This new era of GHG regulation signals a momentous shift for preservation practice and governance, and suggests the need for significant reform of preservation policies in light of climate change.

\section{Methodology}

This study employs a multi-method approach to situate contemporary energy challenges as part of a longer arc of preservation narrative and policy, and to illustrate the implications of new energy policies in an historic urban context. A review of national model energy codes and actual codes across all 50 US states established the extent and variety of exemptions afforded historic buildings. Discourse analysis of government records, energy studies, and reports by preservation organizations and professionals related to historic buildings and energy from the 1970s provided insight into the origins of these exemptions and the rationales that underpinned them. Select research into energy-related heritage policy at the municipal level clarified how preservation agencies are currently tackling energy performance and retrofits through legislation and governance structures. Finally, study of the case of NYC illustrated the significant climate and equity issues raised by the exemption of historic buildings from energy codes, and the new challenges posed by the introduction of the city's 2019 Climate Mobilization Act. Geospatial and statistical methods employed as part of the NYC analysis are discussed below.

\section{Energy and historic preservation discourse and policy development}

The discourse around energy and historic buildings in the United States developed largely as a result of the 1970s oil crisis, which underscored the economic and national security issues associated with energy. A series of research and legislative initiatives intersected to support the rehabilitation of existing, older buildings because of their monetized energy value. Heritage advocates capitalized on these efforts to promote the protection of historic buildings as an energy-saving enterprise, noting energy conservation as "preservation's windfall" (Peirce, 1981).

As early as the 1940s, architecture researchers and professionals raised concerns about the increased use of mechanized heating and cooling to regulate indoor environment and human comfort, and the disassociation of architectural design from climatic conditions (Fitch, 1948). Modern design principles, and particularly the introduction of glazed curtain wall construction, meant less attention was paid to passive design features such as siting, the thermal properties of materials, and operable fenestration. The low cost of fuel further supported the divorce of architectural design and climate. Overall fossil fuel-based energy consumption doubled in the US between 1950 and 1970 (US EIA), and by the mid-1970s, buildings were estimated to account for nearly $50 \%$ of US energy consumption: $15 \%$ associated with embodied energy and more than a third with operating energy (Stein, 1978).

Research begun in the late 1960s investigated the energy required to produce construction materials, which established baseline data about the energy needed to replace a building using comparable materials (Hannon et al., 1976). This formed the foundation of the claim that existing buildings constituted significant embodied energy, and thus their demolition and replacement was an energy cost that could be avoided through reuse. This energy investment translated from the level of buildings to that of communities, as revitalization of existing city centers and neighborhoods was seen as a means to conserve energy at an urban scale, supported by the Housing and Community Development Act of 1974.

However, tax law, zoning codes, and other financial considerations often discouraged reuse and favored new construction, particularly in highly valued urban real estate markets where profitability correlated to leasable floor area (Stein, 1973). The Tax Reform Act of 1976 sought to remedy some of these issues. Prior law allowed tax deductions for the demolition of 
existing buildings and quicker depreciation of the new income-producing buildings that replaced them. The 1976 federal legislation eliminated these financial inducements for demolition and new construction, and instead provided for amortization and accelerated depreciation options to incentivize building rehabilitation. It also allowed taxpayers to amortize over five years the costs associated with rehabilitating a property on the National Register of Historic Places, thereby incentivizing the rehabilitation not only of existing buildings, but also historic buildings (Weber, 1979).

The Advisory Council for Historic Preservation (ACHP), which is mandated to advise the US President and Congress on preservation policy, capitalized on embodied energy as a rationale for conserving historic buildings, producing model cases to demonstrate the contributions of historic preservation to urban revitalization (US ACHP, 1979c) and the positive energy benefits of reuse over demolition and replacement (US ACHP, 1979a, b):

Once energy is embodied in a building, it cannot be recovered and used for another purpose -8 bricks embody energy equivalent to a gallon of gasoline but cannot fuel a car. Preservation saves energy by taking advantage of the nonrecoverable energy embodied in an existing building and extending the use of it (US ACHP, 1979b, p. 14).

Building rehabilitation was also seen as a critical means of reducing operating energy consumption and costs. Private sector investment in rehabilitation required not only financial incentives, but also concomitant development of standards to guide the design of energysaving interventions, and in the case of historic buildings to ensure that such retrofits minimized impact on historic fabric and form. While the research and development of model codes related to energy performance in new buildings advanced expeditiously with government support, more complicated deliberations surrounded those for existing buildings.

Multiple federal agencies were tasked to develop energy-centric rehabilitation and weatherization guidelines, standards, and handbooks in response to various government accountability, funding, and incentive programs (US NBS, 1973; US GSA, 1977; US FEA, 1975; US ERDA, 1976; US HUD, 1975). The National Park Service, representing the Department of the Interior and federal-level historic preservation programs, collaborated with the Department of Housing and Urban Development on rehabilitation principles for older buildings and neighborhoods (US HUD and US DOI, 1977), which served as a precursor to the US Secretary of the Interior Standards for Rehabilitation and Guidelines for Rehabilitating Historic Buildings (NPS, 1977). However, neither addressed energy-conserving strategies; they focused on protecting historic features and materials.

While there was growing agreement that it would be difficult for existing buildings to meet the energy performance codes being established for new construction, a number of distinct challenges emerged from efforts to reduce operating energy through building rehabilitation standards. Whereas new construction had clear gatekeepers (architects, engineers), rehabilitation had a more diverse set of actors with agency to retrofit (owners, building managers, tenants, sometimes design professionals, etc.). Equity and affordability were central to the debate. Many low-income homeowners could not afford to weatherize. Architects and engineers raised concern that rehabilitation standards, if too stringent, would create cost barriers that tax incentives could not adequately offset.

Preservationists were particularly concerned about the implications of rehabilitation and energy codes given the potential effects of retrofits - such as adding insulation, replacing windows, converting heating and cooling systems, etc. - on historic materials and structures. Through a series of position papers, studies, and collaborations with federal agencies, preservation professionals crafted a case to support special consideration and compliance waivers for historic buildings (Gross et al., 1979; Cooke, 1979). A survey of municipal and state authorities from across the country sought to categorize the different ways in which historic buildings were regulated with regard to health and safety codes, including special review 
boards, alternate standards, and code exemptions (Green and Cooke, 1976). A study undertaken by the National Trust for Historic Preservation (National Trust) on behalf of the National Bureau of Standards extended this research to historic preservation projects across the country to further characterize conflicts between performance-based building regulations and historic preservation standards. One of the four most common problems identified in such projects was energy-related: changing existing and/or adding new electrical, mechanical, and ventilation systems (Keune, 1978).

Baird Smith, Historic Architect with the National Park Service, made one of the more compelling and innovative arguments for the special consideration of historic buildings. He noted that existing buildings had to meet increasing levels of performance over the past century, regarding fire egress, accessibility for people with disabilities, energy conservation, and more. There were potential tensions and trade-offs among the different performance attributes to be achieved through codes, and he argued that historic preservation itself should be included as a performance attribute among others:

After all, society is now demanding that old buildings be retained because of their value as a physical resource and that important building features be preserved because of their contribution to our cultural and aesthetic heritage. For these reasons, historic preservation should be included as a performance attribute which must be achieved through a building code (Smith, 1979, p. 36).

While preservationists maintained that the aesthetic and material dimensions of heritage, as a performance attribute, potentially outweighed the reduction of operating energy, evidence that older buildings actually consumed less operating energy proved more elusive. Existing buildings were more difficult to assess, and thus standardize, with regard to energy performance and potential retrofits due to different designs, materials, uses, occupant behavior, climatic conditions, etc. At the time, operating energy studies of office buildings, schools, hospitals, and other building classes in various locales demonstrated wide-ranging inconsistencies in energy intensity, even among those of similar use, construction, and climate (Spielvogel, 1976).

The influence of building age on energy use was examined in several studies during the 1970s. Most found that older buildings did not consistently consume less energy per square foot than newer ones (US DOE, 1980). The National Electrical Manufacturers Association undertook a randomized study of 50 downtown Philadelphia office buildings, roughly a quarter of the city's commercial office building stock at the time, and found that building age was not a factor affecting energy consumption. A study of 383 commercial properties in Baltimore's Central Business District concluded that building age had no effect on energy use. The Building Owners and Managers Association compiled 1977 energy use data for 889 commercial and 216 government office buildings across the United States and found that, "Middle aged buildings - most likely to be approaching the non-prime space category - use less energy than do younger buildings or older buildings, which have in general been renovated" (USDOE, 1980, p. 61). Middle aged in this study constituted those aged 30-39 years (or built between 1938 and 1947 in their dataset).

One research report, a US Department of Energy-sponsored study of existing NYC office buildings, however, identified a correlation between older age and less energy use. It collected data across a range of metrics for 436 office buildings in the city, but used only a 44 building representative sample $(10 \%)$ to determine the statistically significant physical and operational energy-related characteristics of office buildings, and of energy consumption patterns. When grouped in bands by date of first occupancy, it found that on average, older, pre-WWII buildings consumed less energy, while those put in service between 1941 and 1970 were the most energy consumptive (Syska et al., 1977, p. III-20). Yet, this same age category contained the least energy-consumptive building as well, and the most energy consumptive building was in the 1920-40 age range, suggesting wide deviations from the mean and, thus, high variability within the data (see Table 6). 
Despite the limitations and inconsistencies of the data, this study served as an essential, and seemingly singular, source of evidence for preservationists at the time, and it formed a central theme of the preservation community's narrative about older buildings and energy performance (Webb, 2019). The findings were a primary focus of a National Park Service (NPS) publication on the "National Benefits of Rehabilitating Existing Buildings" (Smith, 1977), and were also cited in an "NPS Preservation Brief on Conserving Energy in Historic Buildings" (Smith, 1978). The National Trust took up the mantle with a 1980 conference and pursuant volume, New Energy from Old Buildings, and the findings of this one study - and no others-were cited by multiple contributors, including the organization's president, the deputy secretary of the US Department of Energy, and The New York Times architecture critic, and repeated by the NPS (National Trust, 1981). Referring to the same study, deputy commissioner for Historic Preservation for the State of New York, Ann Webster Smith, boldly announced, "We now have proof that the buildings with the poorest energy efficiency are those that were built between 1941 and 1970" (Smith, 1981, p. 47).

These claims of the multi-faceted energy-saving, and thus economic, value of historic buildings - because of their embodied energy, their operating efficiency, and their density within urban cores - conspired to profoundly influence policy at the federal level, and consequently state and local regulation. The Department of Housing and Urban Development echoed the economic calculus of energy and existing buildings in Congressional hearings about additional tax reform (Bullock, 1978). This helped to substantiate the introduction of a federal tax credit in 1979: anyone who rehabilitated a building 20 years or older received a $10 \%$ credit based on qualified expenditures. This was expanded in 1981 to a three-tiered system: $15 \%$ for buildings $30-39$ years old, $20 \%$ for buildings 40 or older, and $25 \%$ for buildings deemed historic structures [1].

These energy claims also led to the amendment of the 1966 National Historic Preservation Act, augmenting the public purpose of the law to recognize the energy and economic benefits of preservation (NHPA, 1980). A task force appointed by the General Services Administration, which at that time managed over 10,000 buildings, set a precedent for special code consideration for historic buildings within the federal government's ownership in concluding that operating energy could be outweighed by embodied energy metrics (US GSA, 1979). And a 10-volume series of Rehabilitation Guidelines issued by the Department of Housing and Urban Development sanctioned the exemption of historic buildings from energy and other code compliance as follows under "Historic Preservation":

... buildings may be exempted from full code compliance either individually, as a landmark, or collectively, as an historic district. The local designation as a landmark or an historic district may be made by local public landmarks/historic district commissions, which may rely to varying degrees on state historic preservation offices or a listing in the National Register of Historic Places (US HUD, 1980, p. 28).

The development of national model energy codes for both residential and historic buildings increasingly exempted historic buildings with successive versions (Webb, 2019), and these exemptions were reflected in state energy codes.

\section{Changing policy landscape}

The debates of the 1970s effectively argued, with limited data, that heritage performance was more important than energy performance. Today, energy policies are shifting dramatically in response to climate change. There are increasing measures to reduce energy consumption and $\mathrm{CO}_{2}$ emissions in the built environment, as commercial and residential buildings accounted for $40 \%$ of US energy consumption as of 2020. Existing buildings, in particular, constitute an area of priority, and the policy privileges afforded historic buildings are called into question.
Energy and historic buildings 
The US does not have a national energy performance code or standard for new and existing buildings. Rather, the federal government supports the development of "model" codes for commercial buildings, administered by the American Society of Heating, Refrigerating and AirConditioning Engineers (ASHRAE Standard 90.1) and for residential buildings by the International Code Council (International Energy Conservation Code, IECC). States, and in some cases municipalities, may adopt particular versions of the model codes, or may define their own. Per the precedents discussed in the previous section, both the ASHRAE and IECC model codes allow exemptions for historic buildings. A review of state-level energy performance codes across the US found that historic building exemptions are ubiquitous. Exceptions exist where there is no state-level energy performance code (eight states) or where specific provisions are outlined, as in California where non-historic lighting and space conditioning equipment must comply with the state energy code, except where historic character-defining features are threatened.

In all state energy codes, buildings listed on or eligible for the National Register of Historic Places (NR) [2] are considered qualified historic structures and thus exempt, along with those included on state-level registers, and in some cases locally-designated structures. In many states, exemption only requires certification that a building is NR-listed or -eligible, while in others there is more rigorous review of the energy retrofit. For those states that have adopted the 2015 IECC or later, historic building exemption now requires a report indicating that compliance with the code would threaten, degrade, or destroy the historic form, fabric, or function of the building. The State Historic Preservation Office (SHPO) or similar preservation authority serves as the primary entity for certifying that a building is a qualified historic structure and determining whether historic significance and features are negatively impacted, with limited accountability to entities governing the energy performance of buildings. This means that preservation agencies and professionals are largely self-regulating with regard to the energy code compliance of historic buildings, with bias toward preserving historic fabric.

Data collection regarding operating energy consumption for buildings has improved significantly in recent decades (Webb, 2019). Energy audits and benchmarking programs are growing at the state and municipal levels to measure and disclose energy performance for buildings, generally those 10,000 square feet or larger, though it varies by program. NYC and San Francisco, for example, were both early adopters of mandatory benchmarking. As a nonfabric-altering measure, historic buildings are not a priori exempt from these energy use reporting requirements.

With limited regulation to induce energy retrofits to historic buildings, governmentsespecially municipalities - are using other policy tools to encourage property owners to move beyond benchmarking to improve energy efficiency. For example, in Austin, Texas, commercial properties greater than 10,000 square feet and residential properties over 10 years old must all comply with an audit and disclosure law. Rebates and financial incentives are afforded those who undertake retrofits to their buildings, including historic ones, and free weatherization is available to those in low income brackets. This is in addition to the property tax abatement programs for owners who rehabilitate a historic property (austintexas.gov).

Design review serves as the primary regulatory tool at the disposal of most municipal preservation agencies, as physical alterations to locally-designated properties must generally be approved by a preservation commission. Most engage in case-by-case review and deliberations to assess the impacts on historic fabric and significance of a proposed intervention. Though largely informed by federal standards, namely the Secretary of the Interior's Standards for the Treatment of Historic Properties, these-like energy codes at the federal level - serve as informational models, and municipal commissions have a fair degree of discretion in design review processes, depending on the local ordinance. Some municipal governments are taking proactive steps to facilitate retrofitting of historic properties by developing guidance documents; for example, the Washington, DC Preservation Review Board (2019) issued sustainability guidelines for existing and historic buildings. 
Despite encouraging and guiding energy retrofits, photovoltaics in particular remain a point of contention for preservation design review commissions across the US, as they grapple with the perceived negative impact of solar energy on historic fabric and aesthetics (Jamison, 2020; Adler, 2013). These debates were anticipated as early as the 1970s, though limited progress was made within the preservation community until the current climate crisis. A third of the papers included in the aforementioned 1981 National Trust volume, New Energy from Old Buildings, were devoted to renewable energy and solar specifically, and the need to make design review more flexible was portended more than 30 years ago:

The historic preservation movement has not yet fully recognized the important role it can play in the national effort to conserve energy ... The methodology to determine which historic properties can withstand energy-related intervention without adverse effects is not flexible enough. Instead of resisting such intervention, preservationists should become more actively involved in energy retrofit projects so that a more adequate methodology can be developed (Quivik, 1981, p. 147).

A new generation of GHG laws related to the built environment poses additional challenges for preservationists and renews the call for flexibility. Rather than regulate energy performance, these laws regulate the amount of $\mathrm{CO}_{2}$ emissions due to fossil fuel use. Benchmarking data works in concert with such laws to establish existing emissions and target emission reductions, generally for larger buildings. Though the design of building envelopes and systems are not directly regulated as they are with energy codes, reducing $\mathrm{CO}_{2}$ emissions nonetheless likely incurs fabric-altering interventions to one or both. Promoting allelectric pathways to decarbonization will involve the replacement of heating and cooling systems in tens of millions of existing buildings (Waite and Modi, 2020) and further compel energy efficiency improvements to building envelopes. Thus far, historic buildings are not exempt from the few GHG laws that have been adopted in the US. This poses a steep threshold for compliance given the years of energy performance code exemptions afforded to historic buildings.

\section{Examining implications - the case of New York City}

To better understand the relationship of historic buildings and operating energy policy, and the implications of new laws, NYC serves as an illustrative case. Buildings account for $68 \%$ of the city's $\mathrm{CO}_{2}$ emissions (Mayor's Office of Sustainability, 2018), compared to 30 and 35\% at the state and national levels, respectively. And it can be characterized as a "mature energy data market" (Webb, 2019, p. 123), due to historic and contemporary efforts to regulate energy efficiency and $\mathrm{CO}_{2}$ emissions of the built environment.

As noted, NYC was the subject of early operating energy studies, which helped to set the stage for building-related energy policy and undergird the exemption of older, historic buildings (Syska et al., 1977). New York State (NYS) established an energy code, the NYS Energy Conservation Construction Code, in 1979, in response to the National Energy Conservation Policy Act of 1978. It established minimum efficiency standards for building components and systems, and included exemptions for historic buildings on or eligible for the National and State Registers. It also exempted "buildings which have been designated as historically significant by a local governing body that is authorized to make such designations" (New York State Energy Conservation Construction Code, 1991). In 2010, the code was significantly updated in response to the American Recovery and Reinvestment Act of 2009, which advanced energy code stringency across the nation (NYSERDA, 2019). At that time, the exemption for locallydesignated historic buildings was removed from NYS legislation, marking a concerted effort to prioritize and limit noncompliance. In 2009, NYC established its own city-specific energy code, the NYC Energy Conservation Code (Local Law 85), which no longer exempted renovations affecting less than half of the building system and required buildings to meet the most current energy code for any renovation or alteration project. Updates to the state and city codes in 2016
Energy and historic buildings 
and 2020, respectively, continue to exempt only National and State Register-listed and -eligible historic buildings.

In 2009, the city also mandated benchmarking of buildings over 50,000 square feet (Local Law 84; amended to buildings over 25,000 square feet by Local Law 133 in 2016), and required these larger buildings to undergo periodic energy audits and retro-commissioning measures (Local Law 87). The Climate Mobilization Act of 2019 marks one of the most ambitious citylevel legislative initiatives to reduce $\mathrm{CO}_{2}$ emissions, including mandated carbon reduction targets for all buildings over 25,000 square feet, with no exemption for historic structures (Local Law 97). It also requires new and existing buildings undergoing major roof renovations to be covered with solar panels, green roofs, or some combination of the two, and to reduce urban heat hazards (Local Laws 92 and 94). At the state level, the Climate Leadership and Community Protection Act of 2019 (CLCPA) requires NYS to have net-zero carbon emissions by 2050 , with $85 \%$ reductions from all sectors; only the remaining $15 \%$ can come from carbon offsets, in part to ensure equity and prevent adverse impacts on vulnerable communities. The NYC legislation affords more liberal use of carbon offsets by allowing property owners to purchase offsets rather than reduce emissions through retrofits. However, once CLCPA is in full effect it may restrict or preempt this city-level option.

\section{Aims and methods}

These evolving energy policies will likely incur significant challenges for NYC's historic buildings. Many over 25,000 square feet will need to meet energy emission limits by increasing energy efficiency through changes to building envelopes and systems and/or by converting to purchased or onsite-generated renewable energy (per Section 320 of Local Law 97), or by undertaking prescribed retrofits (per Section 321 of Local Law 97). As noted above, the use of offsets for historic buildings will likely be limited. Because many of these buildings are currently exempt from energy codes, there has been no mandate until now to improve efficiency, so the road to compliance may prove complicated.

To test this hypothesis as well as to understand the implications of long-standing exemptions in our present climate crisis, we undertook geospatial and quantitative analyses of NYC's historic built environment in relation to the city writ large. We specifically sought to:

(1) Quantify and spatialize code-exempt historic properties and built area

(2) Quantify and spatialize historic properties and square footage that must comply with new GHG regulation

(3) Examine the geographic distribution and distributive effects of code-exemption and GHG law compliance

(4) Test longstanding hypotheses regarding the correlation between building age and energy efficiency.

The primary unit of analysis for this study is the individual tax lot. A wealth of information for each of NYC's 850,000 plus tax lots is made available from the NYC Department of City Planning's PLUTO dataset. This information, collected from various NYC agencies, is tied to the NYC Department of Finance's Digital Tax Map in the geographic MapPLUTO dataset that is the basis for much of our work [3].

To quantify and spatialize code-exempt historic properties, we used NR geographic data provided by the NYS SHPO. The data was provided in two formats, a polygon file representing all NR-listed districts and individual buildings, and a points file representing all individual resources evaluated by the SHPO for eligibility. These files were vetted and cleansed as required to associate the records to their PLUTO counterparts, and ultimately merged [4]. Any records with PLUTO building area of zero were removed from the dataset 
and not included in subsequent calculations. Similarly, records indicating a tax lot was not subject to the building code based on land use and building class were also removed from the dataset [5]. The result was a geographic dataset indicating NR-listed and -eligible tax lots exempt from energy code compliance.

To identify tax lots exempt from GHG regulations, we collected additional datasets to help us identify exemptions based on the regulatory categories noted in Local Law 133 and Local Law 97. Due to inconsistencies in the PLUTO ownership field [6], we instead used the NYC Department of Citywide Administrative Services' IPIS dataset to identify City ownership [7]. We returned to PLUTO, however, to identify which tax lots meet the regulatory criteria based on floor area [8]. Internet searches were used to identify NYC senior colleges and the extents of their campuses, as well as cultural institutions classified as such by the NYC Department of Cultural Affairs. The online map portal NYCityMap was then used to identify the tax lots associated with each [9].

For benchmarking data, we relied on the Covered Buildings List (CBL) disseminated by the Mayor's Office of Sustainability. This list indicates NYC buildings that are required to comply with GHG laws and contains self-reported energy usage for each building. Since this dataset is organized by building, and because many NYC tax lots contain more than one building, additional work was required to make this dataset compatible with PLUTO [10].

Year of construction is not available in the NR dataset; and while it is an attribute available in PLUTO, the data contained is well-known to be inaccurate and could not be used for this study. The NYC Landmarks Preservation Commission (LPC), however, provides a highly reliable dataset of locally designated historic buildings that includes the year of construction [11]. Since there is a large degree of overlap between NR-listed and -eligible tax lots, and local designations, there is a sufficient sample size for an age analysis. For properties where construction took place over a range of years, the earlier noted year was used.

Census tracts were selected as the geographic unit for aggregated analyses, as they allow for optimal visual analysis of geographic distribution over the broader NYC area. They are also easily associated with US Census American Community Survey (ACS) socio-economic demographic data for race, ethnicity, and poverty, also analyzed for this study [12].

\section{Quantifying and spatializing energy code exemptions}

As noted previously, the 2010 State and City energy codes eliminated the exemption for locally-designated historic buildings. In NYC, this means that any building or district ONLY designated by the NYC LPC must comply with the energy codes, whereby those that are NR-listed or -eligible or dual LPC-designated and NR-listed or -eligible are exempt. In theory, this should have closed a potentially significant loophole. However, the NR includes more than one million properties nationwide and the barriers to listing are fewer than those of local designation. A property owner can generally get a property determined NR-eligible if it is already LPC-designated, allowing them to qualify for the energy code exemption.

While the literature has typically reported historic status in NYC in terms of the number of tax lot properties, it is also crucial to consider this information in terms of built area for the purposes of energy consumption and emissions, as they relate to the square footage of floor space being conditioned (Tables 1 and 2). Across the city, $6 \%$ of properties with conditioned space are formally recognized as historic structures through NYC LPC designation, NR-listing or -eligibility, or both. Even with the 2010 elimination of waivers for local designations, $5.3 \%$ of NYC properties remain exempt from energy codes due to historic status, suggesting that the change in legislation had limited effect. These energy code-exempt properties total more than 847 million square feet distributed across 43,051 properties citywide, meaning that $16 \%$ of the built area of the city is energy code-exempt due to historic status. 
JCHMSD

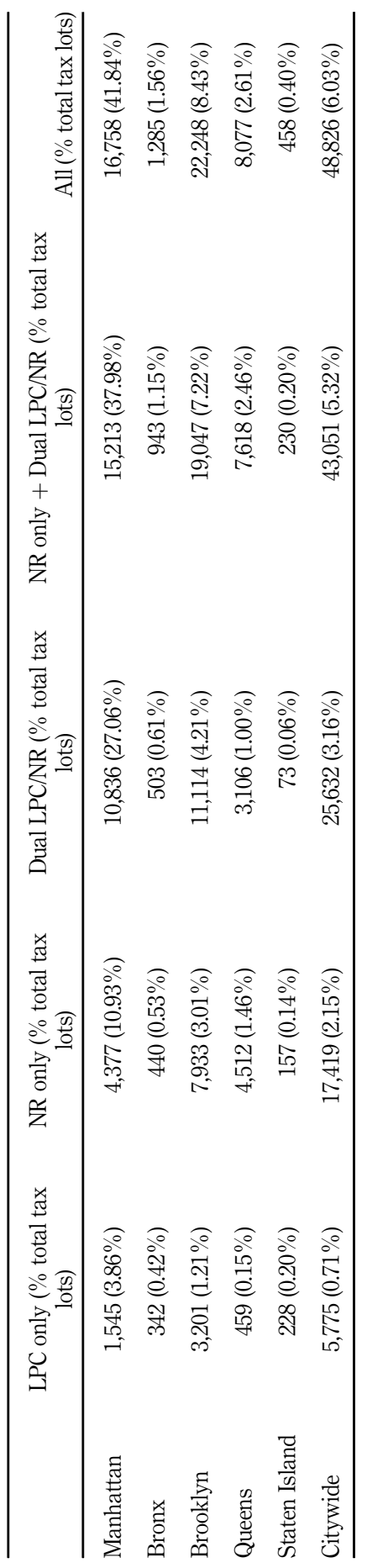

Table 1.

NYC historic

properties by tax lot and percentage 
JCHMSD

Figure 1.

Percentage of NR built area relative to overall built area by NYC census tract
The geographic distribution of these NR energy code exemptions varies significantly. More than two-thirds of this citywide exempted built area is concentrated in Manhattan. Brooklyn is a distant second with $21 \%$ of the exempted built area. At the borough level, almost onethird $(32 \%)$ of the built area of Manhattan is energy code-exempt; this constitutes more than 567 million square feet across 15,213 Manhattan properties.

In order to examine the distributive effects of these exemptions on various publics, we mapped the percentage of NR built area relative to overall built area by census tract (Figure 1) [13]. After eliminating individual data points for census tracts with no buildings or no data on population, we had a set of 2,119 census tracts throughout NYC. Two demographic factorspoverty and race - served as socio-economic characteristics related to energy justice. We found significant correlation citywide and at the borough level in both Manhattan and Brooklyn for race and poverty, meaning the higher percentage of the census tract's built area is NR-listed or -eligible, the more likely it is to have percentages of White population above the city average (Table 3), and the more likely it is to have percentages of poverty below the city average (Table 4) [14]. This suggests that those living in NR buildings and districts tend to be predominantly White and wealthier. From an energy justice perspective, it indicates that this more privileged population is bearing less burden in addressing energy efficiency due to the code exemptions afforded historic properties.

\section{Quantifying and spatializing greenhouse gas regulation}

The introduction of NYC's Climate Mobilization Act now requires many NR buildings over 25,000 square feet to meet emission limits beginning in 2024, with caps becoming more stringent over time, eventually reducing emissions $80 \%$ by 2050 . Through Local Law 84, these larger NYC buildings are included on the CBL. These CBL properties
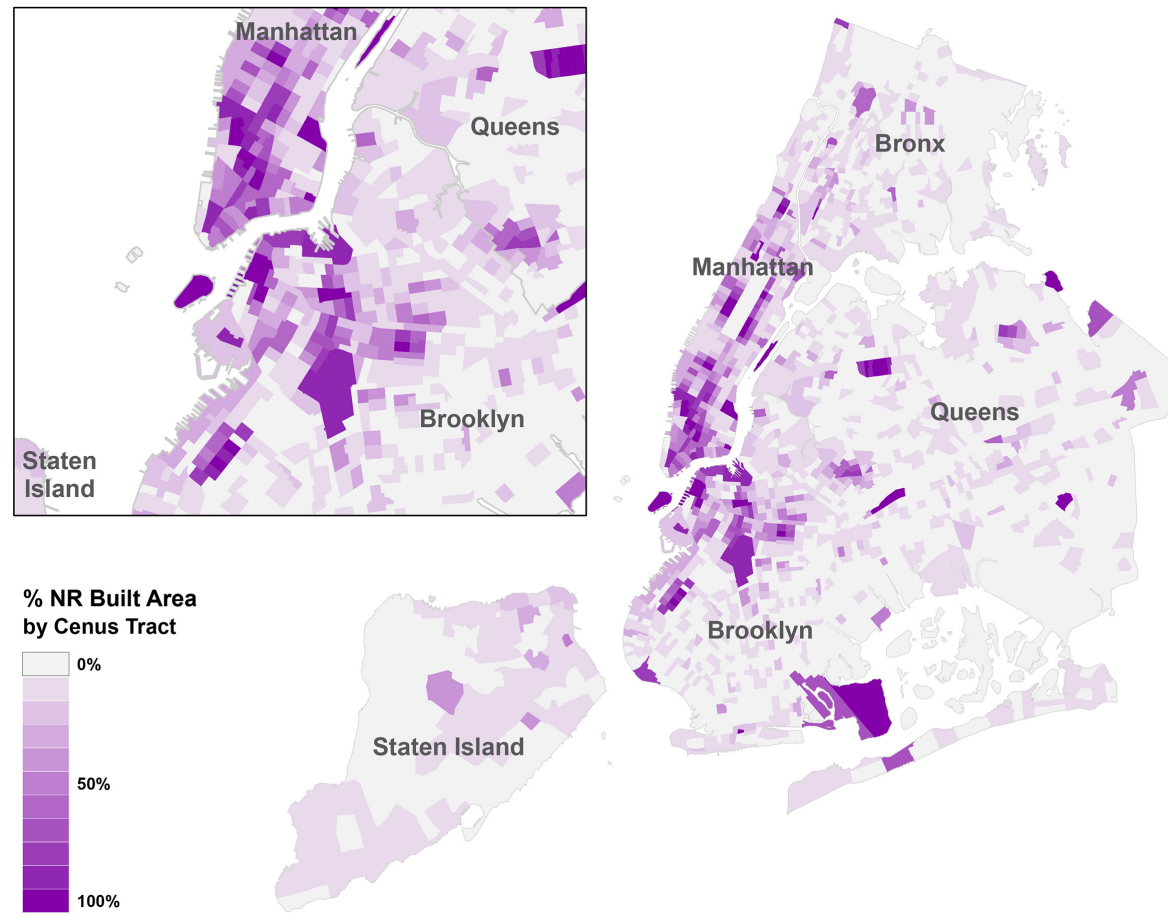


\begin{tabular}{|c|c|c|c|c|c|c|c|}
\hline \multirow[b]{2}{*}{$\%$ Area on NR } & \multirow[b]{2}{*}{ Manhattan } & \multicolumn{4}{|c|}{$\%$ of tracts with $\%$ White population below city average } & \multirow[b]{2}{*}{ Citywide } & \multirow{2}{*}{$\begin{array}{c}\text { Energy and } \\
\text { historic }\end{array}$} \\
\hline & & Bronx & Brooklyn & Queens & Staten Island & & \\
\hline $0-10 \%$ & $41.4 \%$ & $45.1 \%$ & $56.0 \%$ & $57.7 \%$ & $13.1 \%$ & $53.0 \%$ & \\
\hline $10-20 \%$ & $38.5 \%$ & $15.8 \%$ & $51.0 \%$ & $55.6 \%$ & $0.0 \%$ & $49.3 \%$ & \\
\hline $20-30 \%$ & $30.8 \%$ & $33.3 \%$ & $60.0 \%$ & $45.5 \%$ & $0.0 \%$ & $45.6 \%$ & \\
\hline $30-40 \%$ & $27.8 \%$ & $33.3 \%$ & $53.8 \%$ & $66.7 \%$ & $50.0 \%$ & $45.2 \%$ & \\
\hline $40-50 \%$ & $25.0 \%$ & N/A & $43.8 \%$ & $50.0 \%$ & $0.0 \%$ & $51.4 \%$ & \\
\hline $50-60 \%$ & $31.3 \%$ & $0.0 \%$ & $7.1 \%$ & $50.0 \%$ & N/A & $26.3 \%$ & \\
\hline $60-70 \%$ & $28.6 \%$ & $100.0 \%$ & $20.0 \%$ & $50.0 \%$ & N/A & $29.2 \%$ & \\
\hline $70-80 \%$ & $22.2 \%$ & $0.0 \%$ & $25.0 \%$ & $75.0 \%$ & N/A & $27.3 \%$ & Table 3 \\
\hline $80-90 \%$ & $20.0 \%$ & N/A & $0.0 \%$ & $50.0 \%$ & N/A & $29.4 \%$ & Correlation of NR built \\
\hline $90-100 \%$ & $12.5 \%$ & N/A & $25.0 \%$ & $20.0 \%$ & N/A & $17.6 \%$ & area and $\%$ White \\
\hline Correlation & -0.920 & -0.060 & -0.801 & -0.367 & 0.099 & -0.894 & population \\
\hline
\end{tabular}

\begin{tabular}{|c|c|c|c|c|c|c|c|}
\hline \multirow[b]{2}{*}{$\%$ Area on NR } & \multirow[b]{2}{*}{ Manhattan } & \multicolumn{5}{|c|}{$\%$ of tracts with poverty rate below city average } & \\
\hline & & Bronx & Brooklyn & Queens & Staten Island & Citywide & \\
\hline $0-10 \%$ & $50.9 \%$ & $51.5 \%$ & $46.8 \%$ & $45.2 \%$ & $71.7 \%$ & $60.3 \%$ & \\
\hline $10-20 \%$ & $69.2 \%$ & $68.4 \%$ & $45.1 \%$ & $48.1 \%$ & $100.0 \%$ & $54.3 \%$ & \\
\hline $20-30 \%$ & $65.4 \%$ & $66.7 \%$ & $40.0 \%$ & $54.5 \%$ & $100.0 \%$ & $57.4 \%$ & \\
\hline $30-40 \%$ & $66.7 \%$ & $83.3 \%$ & $38.5 \%$ & $66.7 \%$ & $0.0 \%$ & $57.1 \%$ & \\
\hline $40-50 \%$ & $62.5 \%$ & N/A & $62.5 \%$ & $50.0 \%$ & $100.0 \%$ & $57.1 \%$ & \\
\hline $50-60 \%$ & $56.3 \%$ & $100.0 \%$ & $100.0 \%$ & $50.0 \%$ & N/A & $63.2 \%$ & \\
\hline $60-70 \%$ & $64.3 \%$ & $0.0 \%$ & $40.0 \%$ & $50.0 \%$ & N/A & $66.7 \%$ & \\
\hline $70-80 \%$ & $66.7 \%$ & $0.0 \%$ & $75.0 \%$ & $50.0 \%$ & N/A & $72.7 \%$ & Table 4. \\
\hline $80-90 \%$ & $80.0 \%$ & N/A & $80.0 \%$ & $50.0 \%$ & N/A & $70.6 \%$ & Correlation of NR built \\
\hline $90-100 \%$ & $81.3 \%$ & N/A & $66.7 \%$ & $40.0 \%$ & N/A & $73.5 \%$ & property and \\
\hline Correlation & 0.688 & -0.464 & 0.560 & -0.266 & -0.083 & 0.870 & poverty rate \\
\hline
\end{tabular}

are required to benchmark, and the data submitted is used to calculate comparative performance and compliance with caps prescribed by Local Law 97 (hereinafter referred to as the GHG law).

The new GHG law captures a significant amount of NR built area that was previously code-exempt (Table 5). These historic structures must now meet increasingly stringent energy emission limits (per Section 320 of Local Law 97) or address emissions through prescribed retrofits (per Section 321 of Local Law 97). A total of 3,821 NR properties across the city now must comply with the GHG law, constituting $68 \%$ (578.6 million s.f.) of NR built area citywide. To visualize both geographic distribution and spatial concentrations, we mapped GHG-affected NR built area, in actual square footage, by census tract (Figure 2). Concentrations are most prominent in Manhattan. While the GHG law affects only $19 \%$ of all NR properties in Manhattan, these properties comprise more than three-quarters of the NR built area citywide.

To reiterate, the new GHG law regulates $\mathrm{CO}_{2}$ emissions to promote cleaner energy, whereas energy codes regulate the design of building envelopes and systems to promote more efficient energy use. However, reducing $\mathrm{CO}_{2}$ emissions nonetheless incurs fabricaltering interventions to envelopes and/or systems. Thus, NR properties that have not had to comply with energy codes to date but are now subject to the GHG law may face steep challenges. Per 2018 benchmarking reports, approximately $25 \%$ of the NR buildings on the CBL are currently exceeding 2024 emission limits, putting them at a significant disadvantage as $\mathrm{CO}_{2}$ reduction targets continue to become more stringent through 2050. These numbers 


\section{JCHMSD}

Table 5.

GHG law implications for historic buildings

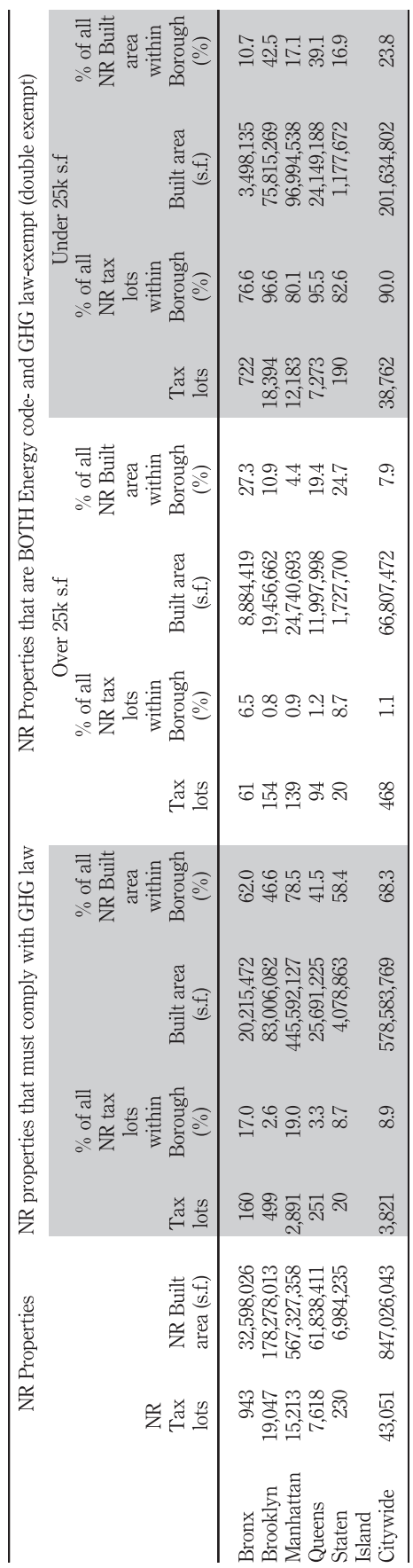



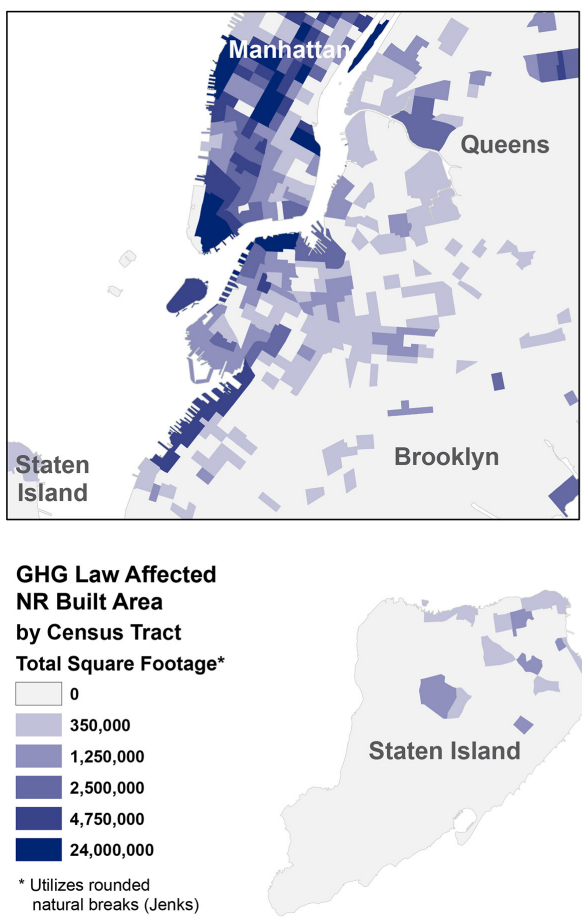

Staten Island

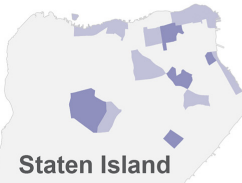

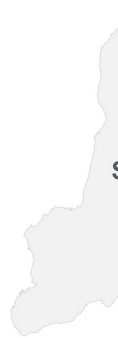

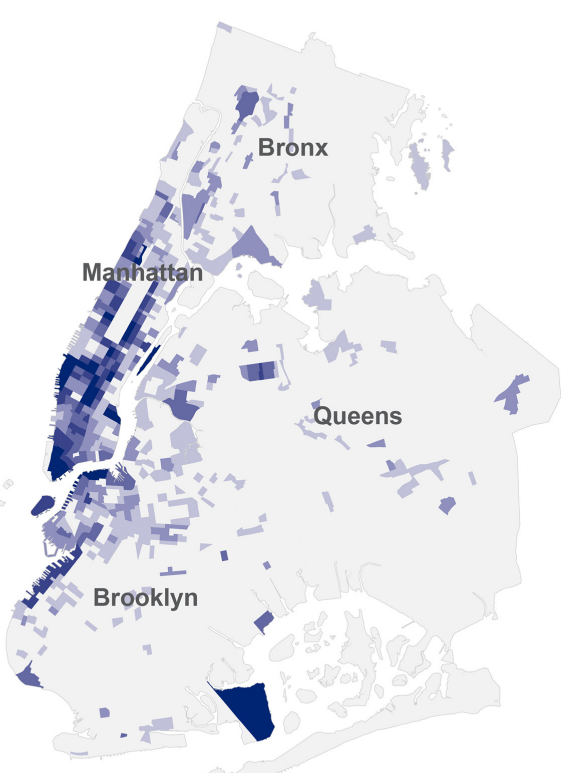

Energy and historic buildings

Figure 2.

Distribution and concentration of GHG law-affected NR built area by NYC census tract

track with non-historic buildings on the CBL, which also show about $25 \%$ currently exceeding, meaning that historic status of buildings does not seem to influence the magnitude of emissions per square foot. In addition, the majority of these historic properties citywide, 2,425 of $3,821(62.5 \%)$, are residential, meaning the expense of retrofitting will be borne by homeowners and housing landlords, who will likely pass on costs to residential tenants.

While the GHG law closes a substantial loophole with regard to regulating the energy emissions of NYC historic buildings, a number of larger NR buildings, which in theory should comply with the GHG law based on building area criteria alone, are still exempted due to their ownership and/or use, including 468 City-owned properties and City-funded cultural institutions. In total, accounting for buildings of all sizes, five percent of the built area of NYC - 268 million square feet across 39,230 properties - are historic buildings that remain exempt from both energy performance codes and emissions regulation. The only energyrelated regulation with which these double exempt properties must comply is the installation of solar panels, green roofs, or some combination of the two when existing roofs are replaced or expanded (Local Laws 92 and 94).

To again visualize the geographic distribution and spatial concentrations of these double exemptions, we mapped this NR built area, in actual square footage, by census tract (Figure 3). These double exemptions are heavily concentrated in Brooklyn and Manhattan: $47 \%$ of the properties and $35.5 \%$ of the built area are located in Brooklyn, and $31 \%$ of the properties and $45.3 \%$ of the built area are in Manhattan. When visually comparing NR built area affected by the GHG law (Figure 2) with double exempt NR built area (Figure 3), the intensity of the former underscores the profound impact the GHG law will have on historic properties. 


\section{JCHMSD}

Figure 3.

Distribution and concentration of double exempt NR built area by NYC census tract
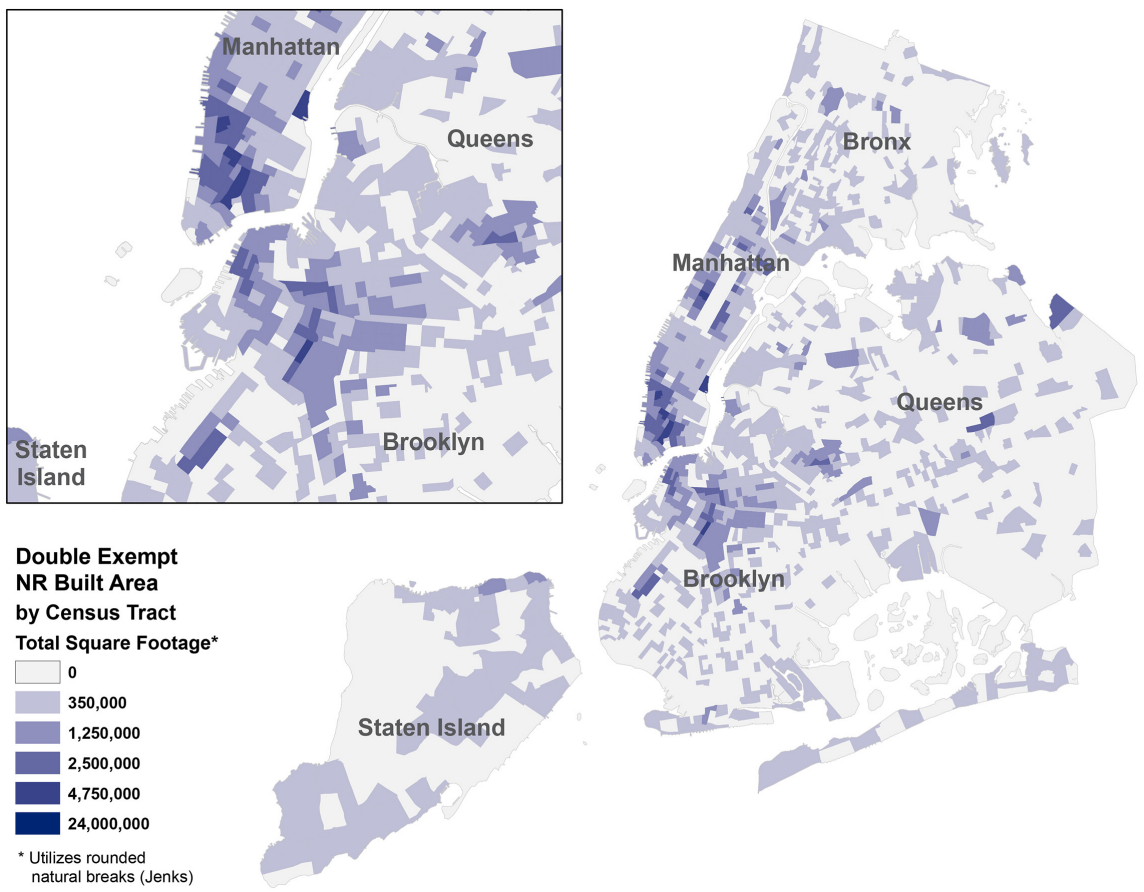

\section{Testing preservation rhetoric}

As noted previously, approximately $25 \%$ of NR buildings in NYC that must comply with the GHG law already exceed their 2024 emission limits, which will become more stringent through 2050, and these exceedance rates comport with those of non-historic buildings. This suggests no readily apparent correlation of historic status to emissions, and accordingly to energy consumption, since NYC's built environment is still largely powered by carbon-based fuels. To test this, we analyzed whether building age, which was so central to the case made for the energy efficiency of older buildings by the preservation community, was potentially correlative to energy consumption today. We applied the same methods as the aforementioned 44-building study of 1977 (Syska et al., 1977, p. III-20) (see Table 6) to a dataset of 2,405 NR-listed/-eligible buildings for which there was 2018 CBL-reported energy consumption data.

We first analyzed a subset of 347 historic office buildings, the building use typology of the 1977 study. As shown in Table 7, average energy use suggests that buildings

\begin{tabular}{lccccc}
\hline $\begin{array}{l}\text { Building } \\
\text { Age }\end{array}$ & $\begin{array}{c}\text { No. of } \\
\text { Bldgs }\end{array}$ & $\begin{array}{c}\text { \% of Bldgs } \\
\text { (of sample } \\
\text { population) }\end{array}$ & $\begin{array}{c}\text { \% of Area } \\
\text { (of sample } \\
\text { population) }\end{array}$ & $\begin{array}{c}\text { Energy } \\
\text { Consumption Range } \\
\left(\mathrm{kBtu} / \mathrm{ft}^{2}\right)\end{array}$ & $\begin{array}{c}\text { Average } \\
\text { Consumption } \\
\left(\mathrm{kBtu} / \mathrm{ft}^{2}\right)\end{array}$ \\
\hline Before 1900 & 3 & 6.8 & 1.1 & $83-115$ & 95 \\
$1901-1919$ & 8 & 18.2 & 12.8 & $76-135$ & 105 \\
$1920-1940$ & 18 & 40.9 & 28.3 & $68-223$ & 109 \\
$1941-1962$ & 12 & 27.3 & 36.2 & $66-198$ & 126 \\
$1962-1970$ & 3 & 6.8 & 21.6 & $78-163$ & 115 \\
\hline
\end{tabular}

Table 6.

1977 Syska et al. Report-NYC office buildings 
constructed prior to 1941 consume less energy per square foot than those dating to 19411970. However, it is again important to consider the difference between the most and least energy intensive buildings in Btu/s.f., alongside average. Range data shows even more variability than in 1977, suggesting that average consumption is a limited and unreliable metric. For example, all of the most egregious energy consumers pre-date 1941, using 221 to $462 \mathrm{Btu} / \mathrm{s.f}$. We then tested other building use typologies, including residential (Table 8) and commercial (non-office) (Table 9), and across all building use typologies (Table 10). In all three of these analyses, buildings constructed between 1941 and 1962 were the best energy performers on average, but the range of per square foot energy consumption was even more significantly variable.
Energy and historic buildings

\begin{tabular}{lccccc}
\hline $\begin{array}{l}\text { Building } \\
\text { Age }\end{array}$ & $\begin{array}{c}\text { No. of } \\
\text { Bldgs }\end{array}$ & $\begin{array}{c}\text { \% of Bldgs } \\
\text { (of sample } \\
\text { population) (\%) }\end{array}$ & $\begin{array}{c}\text { \% of Area } \\
\text { (of sample } \\
\text { population) }(\%)\end{array}$ & $\begin{array}{c}\text { Energy } \\
\text { Consumption } \\
\text { Range }\left(\mathrm{kBtu} / \mathrm{ft}^{2}\right)\end{array}$ & $\begin{array}{c}\text { Average } \\
\text { Consumption } \\
\left(\mathrm{kBtu} / \mathrm{ft}^{2}\right)\end{array}$ \\
\hline Before 1900 & 133 & 38.3 & 16.7 & $1-439$ & 91 \\
$1901-1919$ & 137 & 39.5 & 28.9 & $16-462$ & 90 \\
$1920-1940$ & 57 & 16.4 & 45.2 & $9-417$ & 87 \\
$1941-1962$ & 17 & 4.9 & 7.3 & $29-221$ & 118 \\
$1962-1970$ & 3 & 0.9 & 1.8 & $109-167$ & 129 \\
\hline
\end{tabular}

Table 7 2018 comparison: NYC historic office buildings

\begin{tabular}{|c|c|c|c|c|c|c|}
\hline $\begin{array}{l}\text { Building } \\
\text { Age }\end{array}$ & $\begin{array}{l}\text { No. of } \\
\text { Bldgs }\end{array}$ & $\begin{array}{c}\% \text { of Bldgs } \\
\text { (of sample } \\
\text { population) (\%) }\end{array}$ & $\begin{array}{c}\% \text { of Area } \\
\text { (of sample } \\
\text { population) (\%) }\end{array}$ & $\begin{array}{c}\text { Energy } \\
\text { Consumption } \\
\text { Range }\left(\mathrm{kBtu} / \mathrm{ft}^{2}\right)\end{array}$ & $\begin{array}{c}\text { Average } \\
\text { Consumption } \\
\left(\mathrm{kBtu} / \mathrm{ft}^{2}\right)\end{array}$ & \\
\hline Before 1900 & 363 & 20.2 & 13.1 & 8-391 & 92 & \\
\hline 1901-1919 & 539 & 30.0 & 25.5 & $7-817$ & 92 & Table 8. \\
\hline $1920-1940$ & 715 & 39.8 & 47.8 & $0-1,675$ & 95 & 2018 comparison: NYC \\
\hline 1941-1962 & 129 & 7.2 & 9.7 & $15-196$ & 86 & historic residential \\
\hline 1962-1970 & 16 & 0.9 & 1.1 & $64-557$ & 117 & buildings \\
\hline
\end{tabular}

\begin{tabular}{|c|c|c|c|c|c|c|}
\hline Dates & $\begin{array}{l}\text { No. of } \\
\text { Bldgs }\end{array}$ & $\begin{array}{c}\% \text { of Bldgs } \\
\text { (of sample } \\
\text { population) (\%) }\end{array}$ & $\begin{array}{c}\% \text { of Area } \\
\text { (of sample } \\
\text { population) }(\%)\end{array}$ & $\begin{array}{c}\text { Energy } \\
\text { Consumption } \\
\text { Range }\left(\mathrm{kBtu} / \mathrm{ft}^{2}\right)\end{array}$ & $\begin{array}{c}\text { Average } \\
\text { Consumption } \\
\left(\mathrm{kBtu} / \mathrm{ft}^{2}\right)\end{array}$ & \multirow{6}{*}{$\begin{array}{r}\text { Table 9. } \\
2018 \text { comparison: NYC } \\
\text { historic commercial } \\
\text { buildings (excluding } \\
\text { office buildings) }\end{array}$} \\
\hline Before 1900 & 138 & 33.9 & 29.1 & $6-421$ & 98 & \\
\hline $1901-1919$ & 131 & 32.2 & 27.8 & $0-631$ & 121 & \\
\hline $1920-1940$ & 100 & 24.6 & 31.7 & $0-550$ & 120 & \\
\hline 1941-1962 & 21 & 5.2 & 6.2 & $15-338$ & 90 & \\
\hline $1962-1970$ & 5 & 1.2 & 2.1 & $2-462$ & 170 & \\
\hline Dates & $\begin{array}{l}\text { No. of } \\
\text { Bldgs }\end{array}$ & $\begin{array}{c}\% \text { of Bldgs } \\
\text { (of sample } \\
\text { population) (\%) }\end{array}$ & $\begin{array}{c}\% \text { of Area } \\
\text { (of sample } \\
\text { population) (\%) }\end{array}$ & $\begin{array}{c}\text { Energy } \\
\text { Consumption } \\
\text { Range }\left(\mathrm{kBtu} / \mathrm{ft}^{2}\right)\end{array}$ & $\begin{array}{c}\text { Average } \\
\text { Consumption } \\
\left(\mathrm{kBtu} / \mathrm{ft}^{2}\right)\end{array}$ & \\
\hline Before 1900 & 634 & 24.9 & 16.1 & $1-439$ & 93 & \\
\hline 1901-1919 & 807 & 31.6 & 44.9 & $0-817$ & 96 & Table 10. \\
\hline 1920-1940 & 872 & 34.2 & 75.7 & $0-1,675$ & 97 & 2018 comparison: \\
\hline 1941-1962 & 167 & 6.5 & 14.5 & $15-338$ & 90 & Combined NYC historic \\
\hline 1962-1970 & 24 & 0.9 & 2.4 & $2-557$ & 130 & buildings \\
\hline
\end{tabular}




\section{JCHMSD}

\section{Plate 1.}

The 1919 Federal Reserve Bank of New York (left), designed by architects York and Sawyer, is exceeding its 2024 emissions targets, while Starrett and van Vleck's 1920 American Stock Exchange Building (right) is not

\section{Plate 2.}

Raymond Hood's 1930 RCA Building, now known as 30 Rockefeller Plaza (left), is exceeding its 2024 emissions targets. Shreve, Lamb and Harmon's 1929 Empire State Building is meeting its targets (right)
Individual cases of NR-eligible/-listed NYC historic buildings help to demonstrate this agerelated variability from the perspective of $\mathrm{CO}_{2}$ emissions, based on $2018 \mathrm{CBL}$ reporting. The following plates illustrate age-comparative examples of historic buildings that are exempt from the energy code, but must comply with the new GHG law, and their notable differences (Plates 1-3).

\section{The problem with "old" buildings}

The reliance on age as a metric for rationalizing the operating energy performance of older or historic buildings is highly problematic for many reasons, and contemporary data no longer support it, as Webb (2019) has robustly examined. Age relevant assertions by the preservation community in the 1970 and 1980s ironically failed to account for or anticipate the implications of the time relevant nature of the NR. In addition to meeting criteria for historic, associative, and/or other values, a property must be 50 years old to qualify for the NR. At the time that heritage organizations like the National Trust and the National Park
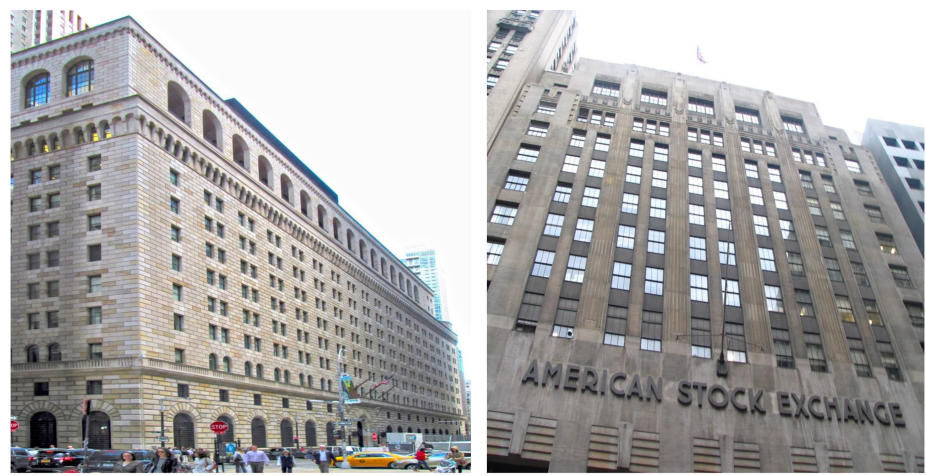

Source(s): (left): Beyond my Ken, CC BY-SA 4.0, via Wikimedia Commons, image date: 2015; (right): RMajouji at fr.wikipedia, CC BY 1.0, via Wikimedia Commons, image date: 2006
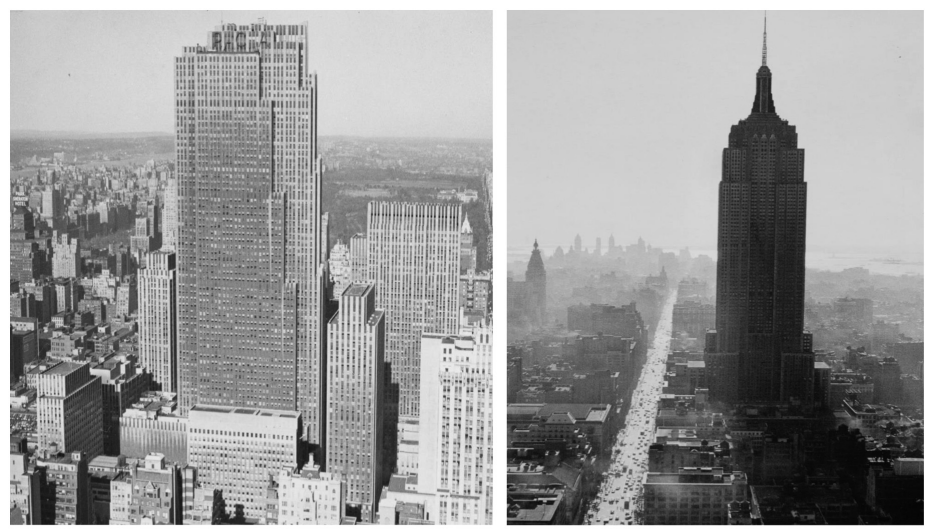

Source(s): Library of Congress, Prints and Photographs Division, Anthony Angel Collection, [30 Rockefeller: LC-DIG-ppmsca-69571; Empire State: LC-DIG-ppmsca-69574], date of images: 1952 
Service were first touting the energy efficiency of older and historic buildings, this included only buildings constructed before the 1930s. In unequivocally declaring "that the buildings with the poorest energy efficiency are those that were built between 1941 and 1970" (Smith, 1981, p. 47), half a century later the preservation community must now reckon with the fact that, today, the buildings potentially eligible for the NR are those constructed before 1971 .

The energy value of age continues to resonate within the preservation community around the discourse of embodied energy, also in problematic ways. As discussed, preservationists in the 1970s advanced embodied energy claims in tandem with operating energy claims, and the early assertions of the economic value of existing buildings due to embodied energy laid the groundwork for tax reform that advantaged buildings because of their age. However, those early embodied energy calculations were based on the estimated energy cost to replace an existing building with a new one of similar construction; they were not based on actual embodied energy over the lifecycle of a building. Metrics for calculating the actual embodied energy of existing buildings are varied and highly debated, due to problems related to data quality and differing methodological approaches (Dixit, 2017). In addition, emerging research on recurrent embodied energy (REE) complicates the age issue further. Initial embodied energy (IEE) reflects the energy cost of initial construction. REE takes into account the embodied energy expended through material repair and maintenance, replacement, and conservation over time. The longer a building is in service, the more REE it consumes. Dixit (2019) cites multiple studies that found REE to outrun IEE in buildings over 50-years old, concluding that REE may be more significant to total embodied energy than IEE.

Lifecycle and avoided impact studies of historic buildings make the case for the environmental benefits of rehabilitating an existing building over constructing a new one (National Trust, 2011; Athena, 2009), but predate much of the research regarding REE and reflect the aforementioned variations in data quality and methods. More importantly, $\mathrm{CO}_{2}$ emissions associated with the built environment are still largely an externality, in economic

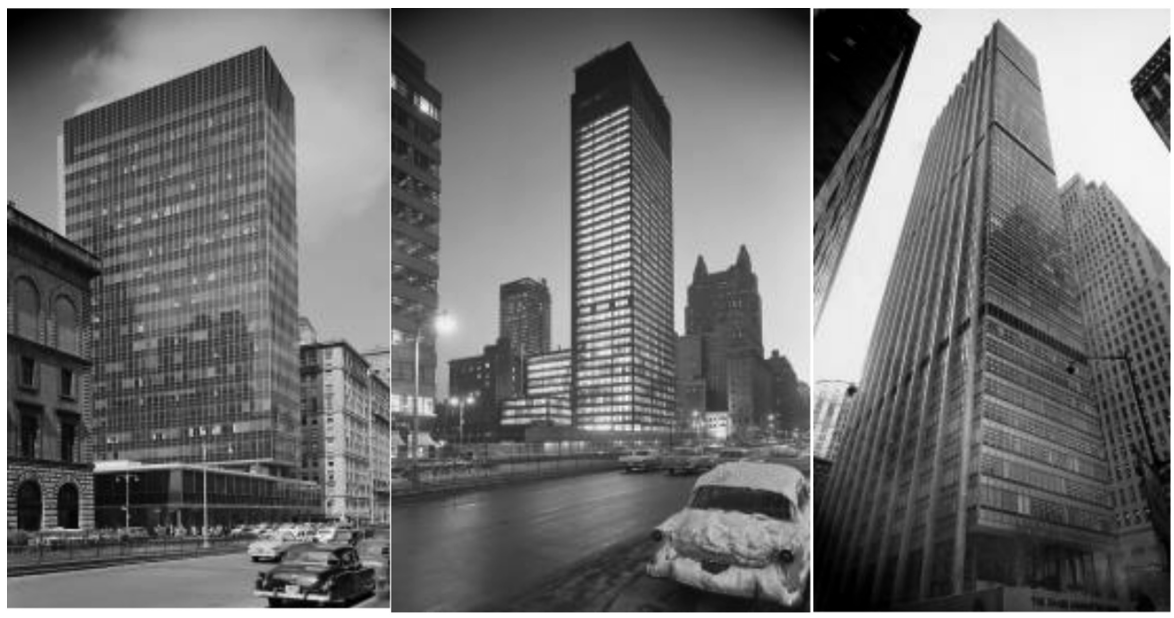

Source(s): Library of Congress, Prints and Photographs Division, (left and middle): Gottscho-Schleisner Collection [Lever: LC-DIG-gsc-5a17254, image date: 1952; Seagram: LC-G612-71723, image date 1958]; (right): NYWT\&S Collection, photo by Walter Albertin, LC-DIG-ppmsca-50536, image date: 1965]
Energy and historic buildings
Plate 3.

Skidmore, Owings, and Merrill's 1950 Lever

House (left) and Mies van der Rohe's 1956 Seagram Building (middle) are both exceeding their 2024 emissions targets. One

Chase Manhattan

Plaza (right), also designed by Skidmore, Owings, and Merrill in 1957 , is meeting its targets 
terms, in most of the US. And there is little incentive to avoid environmental impacts because embodied energy is a sunk cost that cannot be recuperated. Emerging research and policies on circular economies of the built environment pose new opportunities for markets to internalize the social costs of emissions, but these innovations will not necessarily justify the preservation of existing buildings. By incorporating practices of building deconstruction, material reuse and recycling, design for disassembly, and more, circular economy approaches will pose new challenges to preservation norms of protecting architectural form, which cannot be dismissed simply by asserting embodied energy claims. Nor do such claims justify energy code exemptions, as operating energy still generally far exceeds embodied energy over the average lifecycle of a building, though these ratios will likely shift in contexts where buildings are retrofitted to meet net-zero operating emissions.

\section{Conclusions}

In the 1970s, the US preservation community piggybacked its arguments for code exemption and tax-based incentives on operating and embodied energy rationales, which are called into question by evolving research and data standards today. Because public policies provided energy code waivers for NR-listed/-eligible structures early on, and put decision-making power in the hands of preservation professionals and agencies, the preservation enterprise has been largely self-regulating to date. Review processes fundamentally privilege preservation concerns over those of climate.

The position of the US preservation community was established at a time when energy was an economic supply and demand consideration and a national security issue, rather than a climate issue. Contemporary understanding of the causes and consequences of carbonbased fuel consumption and climate change compel new regulatory priorities for the built environment, including historic buildings. This poses technical challenges for historic buildings, but more significantly, it questions the fundamental principles of the preservation enterprise. The assertion that historic preservation is a "performance attribute" is premised on the notion that, to perform as heritage, buildings should retain as much original form and fabric as possible. That notion must evolve considerably in order to make meaningful strides toward climate change mitigation.

New GHG laws and green/cool roof requirements, as evidenced by the case of NYC, will compel the preservation enterprise to confront the problematic constraints of these longstanding tenets. However, such legislation is still nascent in most of the United States; energy codes continue to serve as the primary regulatory tool for reducing energy consumption in new and existing buildings. Even with large-scale shifts to renewable energy generation, existing buildings must undertake electric conversions (cleaner energy) and also reduce energy consumption (less energy). While government agencies and preservation advocacy organizations at the state and municipal levels provide useful information about how to improve energy performance in historic buildings, guidance documents alone neither regulate nor incentivize retrofits.

More timely and intentional action is needed to mitigate climate change by reimagining the relationship of energy and the built environment, and historic buildings could be leading the way. Rather than making continued, and not necessarily evidenced-based, claims that historic buildings are inherently "green," preservationists could choose to be at the forefront of adapting the existing built environment. Eliminating exemptions from energy codes for historic buildings or making the review process for waivers more stringent and informed by energy data are important options to consider. This would jumpstart the kind of evidence-based research and policies that could profoundly shift preservation toward more energy-responsive practices, working in tandem with GHG legislation as it continues to develop. 
In many respects, the longevity of historic buildings signals their capacity to continually adapt in ever-evolving environmental, social, and economic conditions. They could stand as important models as communities grapple with pathways to resilience and adaptation. Their valorization - as culturally significant structures that should persist in the built environment also means that equity concerns must be paramount. The case of NYC demonstrates how historic buildings may allow privileged populations to evade energy performance regulation. The energy burden of historic buildings should not be unevenly distributed and unjustly borne by others today, nor by future generations. Both preservation policy and practice need to pivot in order to address the global climate crisis in effective and equitable ways.

\section{Notes}

1. As of 2020 , there is only a 20 percent federal credit for historic structures; those for older, nonhistoric buildings have been eliminated.

2. "Eligible" means that a property is still in the process of being nominated to the NR, but the State Historic Preservation Office has made an initial determination that it meets listing criteria.

3. PLUTO stands for Primary Land Use Tax Lot Output. MapPLUTO Release 17v1, available for download via the NYC Open Data Portal, was used for this study. For the built area analysis, we used PLUTO attributes including building area (BldgArea), number of buildings per lot (NumBldgs), land use (LandUse), and building class (BldgClass).

4. The NR geographic data was provided by the SHPO in 2018 with a caveat regarding the variable quality of the information. The polygon file was found to have reasonable geographic accuracy, so a spatial join was used to acquire associated PLUTO attributes. The point information was found to have considerable geographic inconsistency. To acquire the necessary PLUTO attributes for the latter dataset, the NYC Department of City Planning's GBAT (Geosupport Batch Address Translator) utility program was used to identify associated tax lot information that would allow for joining with PLUTO. Prior to using the GBAT utility, extensive cleansing actions were taken to rectify the addresses to better guarantee a successful GBAT match. These actions included (but were not limited to) removing ordinal suffixes, leading zeros, correcting common typographic errors, eliminating duplicate records, identifying and eliminating non-building records based on resource name (e.g. cemetery, subway, expressway, etc.), and expanding address range records for districts into individual building records.

5. Two categories in the PLUTO file were identified as helpful to eliminate non-building tax lots: land use (LandUse) and building class (BldgClass). Tax lots categorized as land use 09 (Open Space), 10 (Parking), and 11 (Vacant Land) were eliminated from the dataset, as were tax lots categorized with the following building classes: airports, air fields, terminals, parking garages and lots, beaches, bridges, tunnels, highways, cemeteries, communications and other utilities, easements, golf courses, marinas and yacht clubs, state and government buildings, parks and open space, recreation facilities, pools, playgrounds, police and fire departments, piers, docks and bulkheads, railroad, schools and school yards, stadiums, race tracks, baseball fields, tank farms, tennis courts, terraces/ gardens/cabanas, transportation, and miscellaneous.

6. A spot check of the ownership fields in PLUTO indicated the data in the fields is inconsistent. Filtering by both owner type (OwnerType) and owner name (OwnerName) resulted in contradictory information, e.g. tax lots indicating state ownership by name displaying city ownership as the identified type.

7. IPIS stands for Integrated Property Information System. The 2019 IPIS dataset was downloaded from the NYC Open Data portal for this study (https://data.cityofnewyork.us/HousingDevelopment/IPIS-Integrated-Property-Information-System-/n5mv-nfpy). Cleanup required for this dataset included eliminating duplicate records and manually rectifying missing or incomplete borough, block, and lot (aka BBL) information. The field "City Owned" was used to identify tax lots owned by the City. Note that under LL33, only City-owned buildings larger than 10,000 square feet are exempt.
Energy and historic buildings 
8. A combination of building area, number of buildings, and building class fields was used to identify which tax lots meet regulatory criteria based on size. Exempt tax lots include those with a single building under 25,000 gross square feet, or two or more buildings on the same tax lot totaling under 50,000 gross square feet (LL97). Additional exemptions based on building class were identified as those categorized as $\mathrm{A}^{*}, \mathrm{~B}^{*}, \mathrm{C} 0$ or R6.

9. Cultural institutions were identified using the NYC Cultural Institution Group's website at https:// www.cignyc.org in July 2020. NYCityMap is available at http://gis.nyc.gov/doitt/nycitymap/.

10. The CBL data is self-reported by the property owners themselves, which is the likely culprit for the issues encountered in the dataset. Many records were duplicated or had no/incomplete information, and so were eliminated. An additional issue was the capture of multiple buildings per tax lot in a parent-child relationship. Because our study was conducted on the individual tax lot level, not the building level, only the aggregated information was utilized, while the child records were expunged. The 2019 CBL, available for download from the NYC Open Data portal at https://data.cityofnewyork. us/Environment/NYC-Covered-Building-s-List-2019-/tphr-wtjd, was used for this study.

11. The LPC "Individual Landmark and Historic District Building Database" was downloaded from the NYC Open Data portal at https://data.cityofnewyork.us/Housing-Development/LPC-IndividualLandmark-and-Historic-District-Buil/7mgd-s57w. A standard deviation test of comparative year built data between the NYC LPC dataset and the PLUTO "year built" data for these same resources showed average variability of more than 25 years.

12. This study utilized 2018 ACS data on race, ethnicity, and income, downloaded via http://www. socialexplorer.com for New York State at the census tract level. The tables used for this study are A03001 (Race), A04001 (Hispanic or Latino by Race), and A14006 (Median Household Income in 2018 Inflation Adjusted Dollars). The tables were cleaned up to isolate NYC counties. To analyze White alone (not Hispanic) percentages, we subtracted the field "Hispanic Latino: White Alone" in table A04001 from "Race: White Alone" in table A03001, and normalized by the Total Population for each census tract. To analyze poverty levels, we used the field S1701_C03_001 E (Estimate, percent below poverty level, population for whom poverty status is determined). The 2010 census tract boundaries were downloaded from the NYC Open Data portal at https://data.cityofnewyork.us/CityGovernment/2010-Census-Tracts/fxpq-c8ku.

13. Two data anomalies are worth noting: (1) Much of Roosevelt Island is a single tax lot containing numerous buildings and spanning two census tracts. We divided the built square footage between the census tracts proportionally to the number and size of eligible NR properties contained. (2) The PLUTO dataset reports 24 million square feet of built area at Floyd Bennett Field (tax lot $3,085,911,500)$, where only a handful of low-scale buildings exist. As a correct value was not identified, this anomaly was left as is, affecting census tract 702.02 (Brooklyn).

14. The degree of linear correlation between the percentage of NR-listed/-eligible built area and the race and poverty factors was determined by calculating Pearson correlation coefficients. Pearson coefficients can be values between -1 and 1 , where -1 is a perfect negative correlation (an increase in one variable indicates a decrease in the other), 1 is a perfect positive correlation (an increase in one variable indicates an increase in the other), and 0 is no correlation. Typically, a Pearson coefficient with an absolute value of over 0.5 (that is, less than -0.5 or more than 0.5 ) is the threshold for "significant" correlation in social science literature. For this analysis, we considered sets of census tracts grouped into $10 \%$ intervals of the percentage of NR built area with respect to the total built area for the tract. Pearson correlation coefficients were calculated for these sets to relate the median percentage of NR built area for each set with the percentage of tracts within that set that had White populations or poverty levels below the city average.

\section{References}

Adler, B. (2013), "Old meets new: the debate over photovoltaics in historic districts", Architect: The Journal of the American Institute of Architects, May 9, available at: https://www.architectmagazine. com/technology/old-meets-new-the-debate-over-photovoltaics-in-historic-districts-1_o. 
Athena Sustainable Materials Institute (2009), A Life Cycle Assessment Study of Embodied Effects for Existing Historic Buildings, Merrickville, Ontario, Canada, available at: http://www.athenasmi. org/wp-content/uploads/2012/01/Athena_LCA_for_Existing_Historic_Buildings.pdf.

Bullock, J. Jr (1978), "Testimony, field Hearing on tax Incentives for the preservation of historic structures", US Congress, House, Subcommittee on Oversight, Committee on Ways and Means, 95th Congress, 2nd Session, St. Louis, MO, December 11, Serial 95-118.

Cooke, P.W. (Ed.) (1979), Selected Papers Dealing with Regulatory Concerns of Building Rehabilitation, US Department of Commerce, National Bureau of Standards, Washington, DC.

Dixit, M. (2017), "Life cycle embodied energy analysis of residential buildings: a review of literature to investigate embodied energy parameters", Renewable and Sustainable Energy Reviews, Vol. 79, pp. 390-413.

Dixit, M. (2019), "Life cycle recurrent embodied energy calculation of buildings: a review", Journal of Cleaner Production, Vol. 209, pp. 731-754.

Energy Conservation Construction Code of New York State of 1979.

Fitch, J.M. (1948), American Building: The Forces that Shape it, Houghton Mifflin, Boston.

Green, M. and Cooke, P.W. (1976), Survey of Building Code Provisions for Historic Structures, US Department of Commerce, National Bureau of Standards, Washington, DC.

Gross, J.G., Pielert, J.H. and Cooke, P.W. (1979), Impact of Building Regulations on Rehabilitation: Status and Technical Needs, US Department of Commerce, National Bureau of Standards, Washington, DC.

Hannon, B.M., Stein, R.G., Segal, B., Serber, D. and Stein, C. (1976), "Energy use for building construction”, Final report, March 1, 1976-December 31, 1976, Prepared for the US Energy Research and Development Administration under Contract No. EY-76-S-02-2T91. United States, doi: 10.2172/7301380, available at: https://www.osti.gov/servlets/purl/7301380.

Jamison, P. (2020), "When saving the planet spoils the charm of historic houses", Washington Post, Jan. 19, available at: https://www.washingtonpost.com/dc-md-va/2020/01/19/solar-panelshistoric-houses/.

Keune, R.V. (1978), Assessment of Current Building Regulatory Methods as Applied to the Needs of Historic Preservation Projects, Department of Commerce, National Bureau of Standards, Washington, DC.

Mayor's Office of Sustainability (2018), "NYC carbon challenge progress report - April 2018", available at: https:/www1.nyc.gov/html/gbee/downloads/pdf/NYC $\% 20$ Carbon $\% 20$ Challenge 2018_Progress\%20Report.pdf.

Mayor's Office of Sustainability (2019), "NYC covered buildings list", available at: https://data. cityofnewyork.us/Environment/NYC-Covered-Building-s-List-2019-/tphr-wtjd (accessed 27 July 2019).

National Trust for Historic Preservation (National Trust) (1981), New Energy from Old Buildings, National Trust for Historic Preservation, Washington, DC.

National Trust for Historic Preservation, Preservation Green Lab (National Trust) (2011), The Greenest Building: Quantifying the Environmental Value of Building Reuse, National Trust for Historic Preservation, Washington, DC.

NYSECCC (1991), New York State Energy Conservation Construction Code with 1991 Amendments, available at: https://video.dos.ny.gov/dcea/pdf/nyseccc.pdf.

New York State Energy Research and Development Authority (NYSERDA) (2019), New York State Energy Code Manual for Design Professionals, Albany, New York, available at: https://www. nyserda.ny.gov/-/media/Files/Programs/energy-code-training/design-professionals-manual.pdf.

New York State Historic Preservation Office (2018), National Register of Historic Places Listings in New York State (Polygons) and Building USNs (Points), provided upon author request 22 May 2018.
Energy and historic buildings 
NYC Department of City Planning (DCP) (2010), "New York City census tracts for 2010 US census (18c)", available at: https:/data.cityofnewyork.us/City-Government/2010-Census-Tracts/fxpqc8ku (accessed 21 October 2018).

NYC Department of City Planning (DCP), Information Technology Division (2018), "MapPLUTO 17V1.1", available at: https://www1.nyc.gov/site/planning/data-maps/open-data/dwn-plutomappluto.page (accessed 11 June 2018).

NYC Department of Citywide Administrative Services (DCAS) (2019), "Integrated property information system (IPIS)", available at: https://data.cityofnewyork.us/HousingDevelopment/IPIS-Integrated-Property-Information-System-/n5mv-nfpy (accessed 20 July 2020).

NYC Landmark Preservation Commission (LPC) (2018), "LPC individual landmark and historic district building Database", available at: https://data.cityofnewyork.us/HousingDevelopment/LPC-Individual-Landmark-and-Historic-District-Buil/7mgd-s57w (accessed 01 September 2020).

Peirce, N.R. (1981), “Energy conservation: preservation's windfall”, New Energy from Old Buildings, National Trust for Historic Preservation, Washington, DC, pp. 28-41.

Quivik, F.L. (1981), "Retrofitting with passive solar energy", New Energy from Old Buildings, National Trust for Historic Preservation, Washington, DC, pp. 136-147.

Smith, B.M. (1977), National Benefits of Rehabilitating Existing Buildings, Supplement 11593, Vol. 2, No. 5, US Department of the Interior, Office of Archeology and Historic Preservation, Washington, DC.

Smith, B.M. (1978), Conserving Energy in Historic Buildings, Preservation Brief 3, US Department of the Interior, Office of Archeology and Historic Preservation, Washington, DC.

Smith, B.M. (1979), "Information structure of building codes and standards for the needs of existing buildings", in Cooke, P.W. (Ed.), Selected Papers Dealing with Regulatory Concerns of Building Rehabilitation, US Department of Commerce, National Bureau of Standards, Washington, DC, pp. $17-54$.

Smith, A.W. (1981), "Introduction", New Energy from Old Buildings, National Trust for Historic Preservation, Washington, DC, pp. 46-49.

Spielvogel, L.G. (1976), "Exploding some myths about building energy use", Architectural Record, Vol. 159 No. 2, pp. 125-128.

Stein, R.G. (1973), “Architecture and energy”, Architectural Forum, Vol. 139 No. 1, pp. 38-58.

Stein, R.G. (1978), Architecture and Energy, Anchor Books, Garden City, NY.

Syska, Hennessy and Tishman Research Corporation (1977), Energy Conservation in Existing Office Buildings. Phase 1. Executive Summary, Department of Energy, Washington, DC, doi: 10.2172/ 5669866.

US Advisory Council on Historic Preservation (US ACHP) (1979a), Assessing the Energy Conservation Benefits of Historic Preservation: Methods and Examples, prepared by, Booz, Allen, and Hamilton for Advisory Council on Historic Preservation, Washington, DC.

US Advisory Council on Historic Preservation (US ACHP) (1979b), Preservation and Energy Conservation, Advisory Council on Historic Preservation, Washington, DC.

US Advisory Council on Historic Preservation (US ACHP) (1979c), Preservation and Urban Revitalization, Advisory Council on Historic Preservation, Washington, DC.

US Census Bureau's Community Survey Office (2018), "2014-2018 American community survey (ACS)", available at: http://www.socialexplorer.com (accessed 16 August 2020).

US Department of Energy (DOE) (1980), Energy Use in Office Buildings. Volume 1: Analysis of 1977 Office Building Energy Use as Reported in the Building Owners and Managers Association Data Base, prepared by, General Electric Company for the US Department of Energy, Division of Industrial Energy Conservation, Washington, DC, doi: 10.2172/5034328. 
US Energy Research and Development Administration (US ERDA) (1976), Building Energy Handbook, prepared by, Pope, Evans and Robbins Inc. for the US Energy Research and Development Administration, Division of Building and Community Systems, Washington, DC.

US Federal Energy Administration (US FEA) (1975), Guidelines for Saving Energy in Existing Buildings: Engineers, Architects, and Operators Manual (ECM 2), prepared by, Dubin-MindellBloome Associates, Federal Energy Administration, Office of Energy Conservation and Environment, Washington, DC.

US General Services Administration (US GSA) (1977), Energy Conservation Guidelines for Existing Office Buildings, prepared by the, American Institute of Architects Research Corporation, General Services Administration, Public Buildings Service, Washington, DC.

US General Services Administration (US GSA) Task Force on Historic Preservation (1979), Report to the Administrator of General Services from the Task Force on Historic Preservation, S. Jerome Pratter, Chairman, GSA, Washington, DC.

US Department of Housing and Urban Development (US HUD) (1975), In the Bank, or up the Chimney?: A Dollars and Cents Guide to Energy-Saving Home Improvements, prepared by, Abt Associates for the Department of Housing and Urban Development, Office of Policy Development and Research, Division of Energy, Building Technology, and Standards, Washington, DC.

US Department of Housing and Urban Development (US HUD) (1980), Rehabilitation Guidelines 1980: 1. Guideline for Setting and Adopting Standards for Building Rehabilitation, prepared by the, National Institute of Building Sciences for the US Department of Housing and Urban Development, Office of Policy Development and Research, Washington, DC.

US Department of Housing and Urban Development and US Department of the Interior (US HUD and US DOI) (1977), Guidelines for Rehabilitating Old Buildings: Principles to Consider when Planning Rehabilitation and New Construction Projects in Older Neighborhoods, prepared in, cooperation with the Office of Archeology and Historic Preservation, National Park Service, US Department of the Interior US Department of Housing and Urban Development and US Department of the Interior, Washington, DC.

US Energy Information Administration (US EIA) (2021a), Monthly Energy Review, April, available at: https://www.eia.gov/energyexplained/use-of-energy/.

US Energy Information Administration (US EIA) (2021b), Monthly Energy Review, April, available at: https:/www.eia.gov/energyexplained/energy-and-the-environment/where-greenhouse-gasescome-from.php.

US Housing and Community Development Act of 1974. Public Law 93-383.

US National Bureau of Standards (US NBS) (1973), Technical Options for Energy Conservation in Buildings, US Department of Commerce, National Bureau of Standards, Building Environment Division, Center for Building Technology, Institute for Applied Technology, Washington, DC.

US National Historic Preservation Act (NHPA) Amendments of 1980, Public Law 96-515.

US National Park Service (US NPS) (1977), The Secretary of the Interior's Standards for Rehabilitation and Guidelines for Rehabilitating Historic Buildings, US Department of the Interior, National Park Service, Office of Archeology and Historic Preservation, Washington DC.

US Tax Reform Act of 1976, Public Law 94-455.

Waite, M. and Modi, V. (2020), "Electricity load implications of space heating decarbonization pathways”, Joule, Vol. 4 No. 2, pp. 376-394, doi: 10.1016/j.joule.2019.11.011.

Washington, DC Historic Preservation Review Board (2019), Sustainability Guide for Existing and Historic Properties, District of Columbia Office of Planning - Historic Preservation Office, Washington, DC, available at: https:/planning.dc.gov/sites/default/files/dc/sites/op/publication/attachments/ Sustainability $\% 20$ Guide $\% 20$ for $\% 20$ Existing $\% 20$ and $\% 20$ Historic $\% 20$ Properties.pdf.
Energy and historic buildings 
JCHMSD

Webb, A.L. (2019), "Historic preservation in a new era of building energy data", in Avrami, E. (Ed.), Preservation and the New Data Landscape, Columbia Books on Architecture and the City, New York, pp. 111-123.

Weber, S.F. (1979), Historic Preservation Incentives of the 1976 Tax Reform Act: An Economic Analysis, US Department of Commerce, National Bureau of Standards, Washington, DC.

\section{Corresponding author}

Erica Avrami can be contacted at: eca8@columbia.edu

For instructions on how to order reprints of this article, please visit our website: www.emeraldgrouppublishing.com/licensing/reprints.htm Or contact us for further details: permissions@emeraldinsight.com 